\title{
Cruzando caminhos em Ibicaba: ESCRAVIZADOS, IMIGRANTES SUÍÇOS \\ E ABOLICIONISMO DURANTE A \\ Revolta dos Parceiros \\ (SÃo Paulo, 1856-1857)
}

\author{
Isadora Moura Mota (iD \\ Princeton University
}

Nem só há uma antipatia entre o trabalho livre e o forçado; como este, por assim dizer, depõe no solo germens [sic] tão funestos, que afugentam o outro. Não há [como] ligá-los, repelem-se mutuamente. Assim que, para promover a colonização, força é extinguir a escravatura. ${ }^{1}$

opinião em epígrafe, publicada nas primeiras páginas do jornal
O Philantropo, em 1849, resume a visão de mundo daqueles que
se diziam otimistas em relação ao futuro das relações trabalhistas no Brasil. Em meio a calorosas discussões sobre a extinção do tráfico de africanos para o país, a imigração europeia ganhava popularidade entre liberais como solução ideal para enfrentar a alegada escassez de braços escravizados nas lavouras. Mesmo estampada nas páginas de um periódico emancipacionista, financiado pela Legação Inglesa na corte,

1 O Philantropo, Rio de Janeiro, 22 jun. 1849, p. 2 ש. O jornal foi publicado entre 1849 e 1852 pela Sociedade Contra o Tráfico de Africanos e Promotora da Colonização e Civilização dos Indígenas, uma associação antitráfico que recebia financiamento britânico; Kaori Kodama, "O debate pelo fim do tráfico no periódico O Philantropo (1849-1852) e a formação do povo: doenças, raça e escravidão”, Revista Brasileira de História, v. 28, n. 56 (2008), pp. 407-430; Beatriz Mamigonian, Africanos livres: a abolição do tráfico de escravos no Brasil, São Paulo, Companhia das Letras, 2017, cap. 6. Este e outros jornais utilizados neste artigo estão disponíveis na Hemeroteca Digital da Biblioteca Nacional do Brasil. 
tal perspetiva encontrava esteio em parte da elite proprietária de terras e gente em São Paulo. Ali tiveram lugar as primeiras experiências privadas com as chamadas "colônias de parceria”, dirigidas por fazendeiros que contratavam imigrantes despossuídos para produzir café onde antes vigorava somente o trabalho negro. Tal como o editor d'O Philantropo, tais iniciativas partiram do pressuposto de que a superioridade do trabalho livre, com o tempo, destruiria a escravidão por dentro, escancarando as supostas baixa produtividade e imoralidade da força de trabalho escravizada. Braços livres, quem sabe, também contribuiriam para dirimir o perigo de insurreições escravas durante a transição.

A realidade, no entanto, mostrou-se bastante diferente, dado que os fazendeiros paulistas responderam à crise do escravismo com as ferramentas de opressão que conheciam. ${ }^{2}$ Em vez da substituição dos escravizados, a parceria foi implantada como mais um regime coercitivo de trabalho, fazendo crescer as tensões no complexo cafeeiro. Não surpreende, portanto, que um dos mais abastados traficantes de africanos da província de São Paulo tenha sido pioneiro do capitalismo brasileiro. Em 1846, o então ministro da justiça Nicolau Pereira de Campos Vergueiro (1778-1859) fundou, em sua fazenda Ibicaba, na Vila de Limeira (hoje Cordeirópolis), a primeira colônia de imigrantes alemães e suíços baseada no sistema de parceria para a produção de café. ${ }^{3}$ No entender de Vergueiro, o empreendimento era um verdadeiro feito patriótico destinado a combater “a decadência da agricultura que a abolição do comércio dos escravos

2 Sobre espaços de ambiguidade entre a escravidão e a liberdade, ver: Sidney Chalhoub, A força da escravidão: ilegalidade e costume no Brasil oitocentista, São Paulo: Companhia das Letras, 2012; João José Reis, Ganhadores: a greve negra de 1857 na Bahia, São Paulo: Companhia das Letras, 2019; Camillia Cowling, Conceiving Freedom: Women of Color, Gender, and the Abolition of Slavery in Havana and Rio de Janeiro, Chapel Hill: University of North Carolina Press, 2013; Frederick Cooper, Thomas C. Holt e Rebecca J. Scott, Beyond Slavery: Explorations of Race, Labor, and Citizenship in Postemancipation Societies, Chapel Hill: University of North Carolina Press, 2000.

3 Sheila de Castro Faria, “Nicolau Pereira de Campos Vergueiro” in Ronaldo Vainfas (org.), Dicionário do Brasil Imperial (1822-1889) (Rio de Janeiro: Objetiva, 2002), pp. 550-553. 
ameaçava” por meio da introdução do trabalho livre. ${ }^{4}$ Uma década após a fundação da Colônia Senador Vergueiro em Ibicaba, porém, a vinculação semisservil da parceria inspirou um dos mais famosos conflitos trabalhistas do Oitocentos, a chamada Revolta dos Parceiros. ${ }^{5}$ Sob a liderança do mestre-escola suíço Thomas Davatz, em 1856, o movimento representou o ápice de uma crise nas relações entre a Casa Vergueiro e os imigrantes, que já se manifestara em numerosas deserções, endividamento em massa e queixas de colonos ao Consulado da Suíça no Rio de Janeiro.

Considerada um marco da história da imigração no Brasil, a Revolta dos Parceiros ganhou notoriedade por meio de narrativas que pouco contestaram a ideia de que uma antipatia fundamental separou as experiências de trabalhadores livres e escravizados durante o século XIX. Ao ignorar a possibilidade de que os escravizados pelo senador Vergueiro teriam compartilhado vivências com aqueles contratados para substituí-los, a historiografia apagou não apenas a memória de uma conspiração negra em 1856, mas também, com ela, décadas de lutas negras pela liberdade que se cruzaram com a chegada de imigrantes europeus no oeste paulista. Ainda que tingidas com os exageros próprios do medo senhorial, fontes históricas revelam que, no início de 1857, tanto a família Vergueiro quanto as autoridades brasileiras lidaram com mais do que um levante de

4 Arquivo Público do Estado de São Paulo (APESP), São Paulo, Secretaria de Agricultura, Comércio e Obras Públicas da Província, cx. C7112, Nicolau Vergueiro a José Tomás Nabuco de Araújo, São Paulo, 6 jan. 1852.

5 Sérgio Buarque de Hollanda, "Prefácio do Tradutor” in Thomas Davatz, Memórias de um colono no Brasil (São Paulo: Livraria Martins, 1941), pp. 28-29; Sérgio Buarque de Holanda, “As Colônias de Parceria” in Holanda, Pedro Moacyr Campos e Boris Fausto (orgs.), História geral da civilização brasileira (São Paulo: Difusão Européia do Livro, 1967), tomo II, v. 3, pp. 245-260; Warren Dean, Rio Claro: um sistema brasileiro de grande lavoura 1820-1920, Rio de Janeiro: Paz e Terra, 1977; Emília Viotti da Costa, Da senzala à colônia, São Paulo: Editora Unesp, 2010; José Sebastião Witter, A revolta dos parceiros, São Paulo: Editora Brasiliense, 1986; e "Ibicaba revisitada” in Tamás Szmrecsányi e José Roberto do Amaral (orgs.), História econômica da independência e do império (São Paulo: ABPHE, 1996), pp. 131-144; José Eduardo Heflinger Jr., O sistema de parceria e a imigração européia, Limeira: Unigráfica, 2014; A revolta dos parceiros na Ibicaba, São Paulo: Unigráfica, 2009; Ibicaba: o berço da imigração européia de cunho particular, Limeira: Unigráfica, 2007. 
colonos suíço-alemães em Limeira. Como resumiu o ministro da Justiça José Tomás Nabuco de Araújo, se antevia naquele ano uma rebelião generalizada dos trabalhadores do oeste paulista, talvez dirigida pelo suíço Oswald “conhecido por sua adesão aos princípios do comunismo, o qual pretende estabelecer uma república, contando para isso com o auxílio de todos os colonos Alemães e Suíços, e mesmo dos escravos que não duvidará levar à insurreição”. ${ }^{6}$

Apesar de míope em relação à dinâmica interna do ativismo cativo - sempre descrito como derivado de influências externas -, a fala de Nabuco de Araújo chama atenção para o fato de que tal ativismo floresceu no interior das primeiras experiências do Brasil com o trabalho livre.7 Quando examinada no contexto da longa tradição rebelde das comunidades negras paulistas, a Revolta dos Parceiros revela que colonos e escravizados, por vezes, fizeram leituras semelhantes do processo de abolição nas Américas. Escolados em décadas de tensões anglo-brasileiras em torno da extinção do tráfico de africanos, escravizados paulistas há muito esperavam que uma intervenção militar da Inglaterra ou da França destruísse o cativeiro no Brasil. Tais expectativas tinham raízes tanto nas declarações de imigrantes quanto no pensamento geopolítico negro que se desenvolveu a contrapelo do sentimento anti-britânico ao longo do século XIX. Aqui me refiro ao fato de que a imaginação política dos escravizados também se baseava numa articulação estratégica das geografias históricas de seu tempo. Eles viam os ingleses como aliados da causa da emancipação

6 Arquivo Nacional (ANRJ), Rio de Janeiro, Série Justiça (SJ), Ofícios de Presidentes de Província (IJ1-512), José Tomás Nabuco de Araújo para o vice-presidente de São Paulo, Antônio Roberto de Almeida, 24 fev. 1857.

7 Sobre as relações entre imigrantes e escravos, ver: Felipe Landim Ribeiro Mendes, "Ibicaba revisitada outra vez: espaço, escravidão e trabalho livre no oeste paulista", Anais do Museu Paulista,, v. 25, n. 1 (2017), pp. 301-357; Rafael de Bivar Marquese, "Exílio escravista: Hercule Florence e as fronteiras do açúcar e do café no Oeste paulista (1830-1879)”, Anais do Museu Paulista, v. 24, n. 2 (2016), pp. 11-51; e “Capitalismo, escravidão e a economia cafeeira do Brasil no longo século XIX”, Saeculum: Revista de História, n. 29 (2013), pp. 289-321; Giralda Seyferth, "Imigração, colonização e a questão racial no Brasil”, Revista USP, n. 53 (2002), pp. 117-149; Luiz Felipe de Alencastro, "Escravos e proletários", Novos Estudos CEBRAP, n. 21 (1988), pp. 30-56. 
porque liam a assimetria das relações de poder entre o Brasil e a Inglaterra da perspectiva da liberdade. Apesar de geralmente descrita como foro de atores de estado e limitada ao campo diplomático, a geopolítica pode ser vista também como uma prática narrativa subalterna, uma leitura possível da interdependência entre a ordem internacional e as realidades cotidianas da escravidão brasileira.

Numa entrevista concedida em fevereiro de 1857, por exemplo, Thomas Davatz assim descreveu as motivações do motim dos colonos na Fazenda Ibicaba:

3o. que contam com os mais Suíços da Província em número talvez de 5000 para defender seus direitos com arma na mão, caso que isto for conveniente, número que era suficiente para se apoderar mesmo da Província inteira querendo.

4o. que conforme as afirmações de muitos de seus compatriotas podem contar com os pretos, escravos das Fazendas que estão ansiosamente esperando uma sublevação.

A mais disto estão combinando, que as Forças navais de França e Inglaterra não se reúnem debalde em Rio de Janeiro; dizendo o Davatz que lhes (aos colonos) foi comunicado por homem fidedigno e muito sincero amigo dos Suíços, que estas duas nações só esperam ter um motivo ou pretexto para invadir o Brasil em razão de abolir a escravatura, tanto dos pretos quanto dos escravos brancos (como se chamam a si mesmos). ${ }^{8}$

As palavras de Davatz revelam que, ao funcionar como metáfora central definidora do lugar do Brasil na imaginação de suíços e alemães, a escravidão forneceu a colonos e escravizados uma linguagem comum sobre os mundos do trabalho oitocentista. Em Ibicaba, populações negras atentas ao nascente discurso emancipacionista ouviram colonos

8 ANRJ, SJ, IJ1-512, Cópia da carta de H. Ullmann para o Senador Nicolau Vergueiro, 23 fev. 1857. 
compararem os abusos de seus contratos à existência de "escravidão branca” nos cafezais. O encontro dessas culturas políticas contribuiu para o desenvolvimento de articulações originais do abolicionismo atlântico que estiveram na origem de diversas conspirações negras em São Paulo. ${ }^{9}$ Este artigo retorna à Revolta dos Parceiros para explorar como as relações entre colonos e escravizados aceleraram a circulação de ideias sobre o fim da escravidão na segunda metade do século XIX. Imigrantes europeus como Davatz, é bom ressaltar, jamais se viram em pé de igualdade com os negros, a quem consideravam racialmente inferiores e miseráveis; ambos, no entanto, debateram a influência estrangeira na política brasileira, imaginaram o futuro como agricultores independentes e trocaram informações sobre as ideologias libertárias de seu tempo. Refletir sobre o tumultuoso (e nada linear) processo de "transição para o trabalho livre” no Brasil, portanto, é ir além dos debates sobre o pioneirismo de Vergueiro para resgatar, também, o impacto da colonização sobre comunidades escravizadas.

\section{Imigração em terra de escravidão}

A imigração estrangeira no sudeste brasileiro remonta ao reino de D. João VI, quando um grupo de famílias suíças constituiu a primeira colônia contratada pelo governo português nas serras do Rio de Janeiro. ${ }^{10}$ No

9 Sobre a importância da geopolítica para o protesto dos escravizados, ver: Julius S. Scott, The Common Wind: Afro-American Currents in the Age of the Haitian Revolution, London; New York: Verso, 2018; Ada Ferrer, Freedom's Mirror: Cuba and Haiti In the Age of Revolution, New York: Cambridge University Press, 2014; Hilary Beckles, "The Wilberforce Song: How Enslaved Caribbean Blacks Heard British Abolitionists,” Parliamentary History, v. 26, Supplement (2007), pp. 113-126; Flávio dos Santos Gomes, A hidra e os pântanos: mocambos, quilombos e comunidades de fugitivos no Brasil, séculos XVII-XIX, São Paulo: Polis, 2005.

10 A colônia suíça de Nova Friburgo foi fundada em 1818. Nos anos 1820, muitos dos primeiros colonos chegados ao Brasil almejavam ser cafeicultores escravistas. O suíço Henri Bom, por exemplo, tornou-se proprietário de escravos em Cantagalo. Sheila de Castro Faria, “Ouro, porcos, escravos e café: as origens das fortunas oitocentistas em São Pedro de Cantagalo, Rio de Janeiro (últimas décadas do século XVIII e 
entanto, um esforço mais concentrado para atrair colonos europeus ocorreu na década de 1840, quando o Estado brasileiro se pôs a debater a passagem de uma nova lei de terras e a cessação do tráfico de africanos para o país. ${ }^{11}$ Em seus primeiros estágios, os projetos de imigração contaram sempre com algum financiamento do governo imperial e assumiram dois formatos distintos: núcleos coloniais patrocinados pelo Estado em terras devolutas e colônias privadas compostas por imigrantes em sistema de parceria no Vale do Paraíba. ${ }^{12}$ As primeiras baseavam-se na pequena propriedade agrícola familiar em regiões de fronteira e as segundas atendiam aos interesses da cafeicultura paulista, empregando trabalhadores rurais sob contrato. Em ambos os casos, a empresa colonial expressava os ideais civilizatórios da elite brasileira, interessada em neutralizar maiorias demográficas negras criadas pelo apego à escravidão. As primeiras experiências brasileiras com a adoção de mão de obra imigrante tiveram, muitas vezes, caráter provisório devido à escassez de recursos, precária supervisão estatal e expectativas frustradas de sucesso econômico por parte dos colonos.

Em São Paulo, trabalhadores escravizados e europeus trabalhavam lado a lado na expansão da fronteira agrícola cafeeira. Com vidas que corriam paralelas nas mesmas fazendas, ambos ocasionalmente compartilhavam queixas sobre práticas de trabalho abusivas ou trocavam conhecimentos sobre o mundo que vivenciavam através da passagem por esquemas de migração global. A geopolítica negra era feita desses encontros - como os que tiveram lugar em Ibicaba. Fundada em 1817, no condado de Limeira, hoje Cordeirópolis, a plantação de açúcar virou

primeiras do XIX)”, Anais do Museu Paulista, v. 26 (2018), pp. 1-23; Henrique Bon, Imigrantes: a saga do primeiro movimento migratório organizado rumo ao Brasil às portas da independência, 2a ed., Nova Friburgo: Imagem Virtual, 2004.

11 Tanto a Lei Eusébio de Queirós quanto a Lei de Terras ( $n^{\circ}$ 601) foram aprovadas em 1850.

12 Sobre a presença escrava nas colônias imperiais, ver: Paulo Moreira e Miquéias Henrique Mügge, "Negros em terras de alemães: escravos e libertos em zona de imigração europeia - Stumpf, Schneider e seus escravos” in Véra Lucia Maciel Barroso et al. (orgs.), Raízes de Nova Hartz (Novo Hamburgo: Um Cultural, 2012), v. 2, pp. 387-402; Alana Fraga do Carmo, "Colonização e escravidão na Bahia: a colônia leopoldina (1850-1888)”, Dissertação (Mestrado em História), Universidade Federal da Bahia, Salvador, 2010. 
cafezal na década de 1830, ganhando fama internacional como pioneira na introdução da mão de obra imigrante no cultivo do café. Em Ibicaba, o senador Nicolau Vergueiro e seus filhos implantaram o até então inédito sistema de parceria, em que imigrantes trabalhavam em condições contratuais raramente vistas no Brasil. ${ }^{13}$

Figura 1

Panorama da Fazenda Ibicaba, século XIX

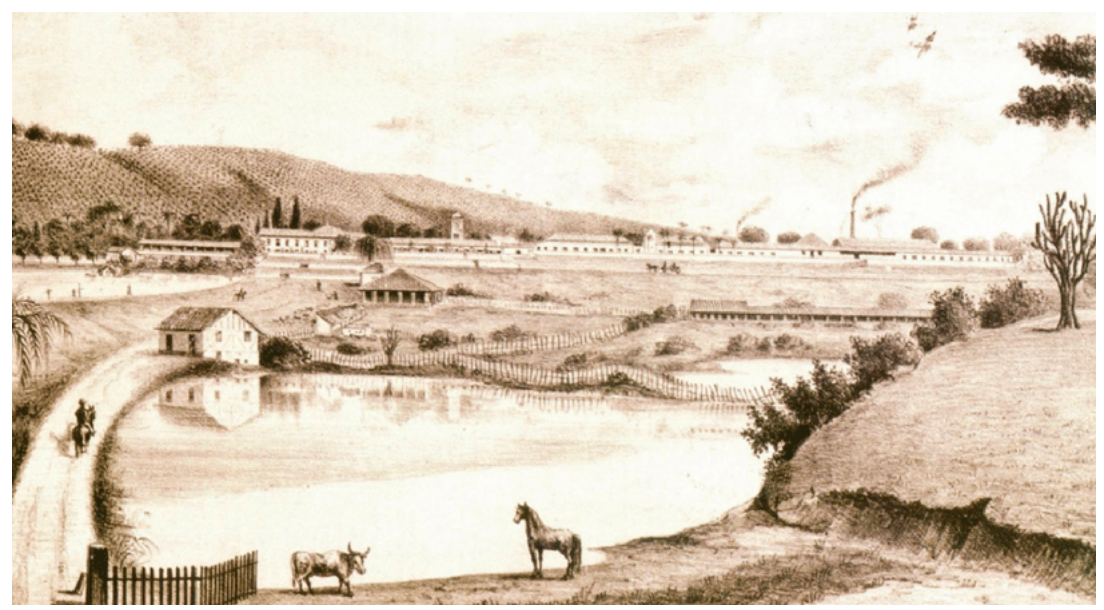

Fonte: Banco de imagens do Carlota Schmidt Memorial Center, Álbum José Vergueiro.

Advogado, comerciante e um dos fazendeiros mais ricos da província de São Paulo, Nicolau Vergueiro foi deputado estadual durante a maior parte da sua vida, atuando em diversos ministérios e no Parlamento brasileiro desde a sua eleição para a Assembleia Constituinte de 1823. O senador fazia parte do grupo político que apoiou o chamado Golpe da Maioridade que, em 1840, elevou ao trono o jovem imperador Dom

13 Djalma Forjaz, O senador Vergueiro: sua vida e sua época (1778-1859), São Paulo: Officinas do Diário Official, 1924; Heflinger Jr., O sistema de parceria; José Sebastião Witter, Ibicaba, uma experiência pioneira, São Paulo: Edições Arquivo do Estado, 1982. 
Pedro II. A maioria de seus contemporâneos se referia a Vergueiro como empresário visionário a presidir a transformação de uma economia de exportação profundamente afetada pelos custos crescentes do trabalho cativo. O senador promoveu os primeiros experimentos com a imigração portuguesa em 1841, abrindo caminho para a criação de outras colônias particulares na província. Em 1846, ele foi convidado pelo presidente de São Paulo (em nome do governo imperial) a receber colonos e associou-se, então, aos filhos Luís e José, constituindo a Sociedade Vergueiro \& Cia. A empresa com escritórios em Santos e Hamburgo, além de agentes de emigração em Portugal, Suíça e Alemanha, começou trazendo colonos somente para Ibicaba; e eventualmente expandiu suas operações para distribuir trabalhadores para outras colônias de parceria do oeste paulista. Entre as décadas de 1840 e 1870, estima-se que entre cinco e oito mil imigrantes tenham chegado ao interior de São Paulo - a maioria proveniente dos Estados da Alemanha e da Confederação Suíça. ${ }^{14}$

Os esquemas de imigração da Casa Vergueiro contaram com a experiência do senador no ramo do comércio negreiro. Em 1843, ao arrepio da lei que tornara o negócio ilegal em 1831, Nicolau Vergueiro comprou três navios americanos para uso no transporte tanto de africanos como de imigrantes portugueses e alemães para Limeira. ${ }^{15}$ Em janeiro de 1844, porém, uma ação britânica interrompeu o fluxo de trabalhadores para Ibicaba. O navio Frolie capturou o brigue português Caçador no Rio Bertioga, que trazia 600 africanos para desembarque na fazenda. ${ }^{16}$ De acordo com denúncia da Legação Britânica na corte, “o notório Negociante de escravos, Vergueiro”, se beneficiava da ascendência política que exercia sobre autoridades paulistas. O cônsul Hamilton reclamou ao governo imperial que o fazendeiro havia obtido licença do presidente de São Paulo "para que os vapores sob a agência de Vergueiro passem à Fortaleza de Santos, sem serem visitados pelas autoridades locais, tendo

14 Hollanda, "Prefácio do Tradutor", p. 29.

15 Alencastro, "Escravos e proletários”, p. 37.

16 Hollanda, "Prefácio do Tradutor”, p. 32. 
desta forma, este contrabandista, meios mais facilitados para conduzir os escravos ao Porto, e dali trazê-los ad libitum". ${ }^{17}$

Em 1847, os primeiros colonos germânicos chegaram à Ibicaba para formar oficialmente a "Colônia Senador Vergueiro", assentamento estabelecido ao lado da plantação de café preexistente e trabalhada, então, por 215 escravizados. O reverendo James Fletcher, pastor presbiteriano americano que visitou Ibicaba em 1854, assim descreveu a propriedade, revelando que Luís Vergueiro compartilhava com a classe política de seu tempo a crença de que homens livres teriam mais interesse nos resultados da lavoura que os escravizados:

Ibicaba é uma pequena plantação, contendo apenas cinco ou seis milhas quadradas; mas, nas suas proximidades, os Vergueiros possuem uma fazenda, não tão bem cultivada, porém três vezes maior. Em Angélica possuem uma outra plantação, bem adaptada à cultura de café, que mede doze léguas de circunferência. Até agora os pretos foram empregados nessa grande fazenda; mas é intenção do proprietário, introduzir, logo que possível, trabalhadores brancos e livres. Perguntei ao sr. Luiz Vergueiro se era mera filantropia que inspirava seus esforços para introduzir o trabalho livre, respondeu, muito pronta e decididamente: “Achamos o trabalho do homem que tem sua própria vontade e interesses na empresa, muitíssimo mais aproveitável do que o trabalho do escravo". ${ }^{18}$

17 Hamilton Hamilton para Ernesto Ferreira França, Rio de Janeiro, 17 de dezembro de 1844, apud: Heflinger Jr., Ibicaba: o berço da imigração européia, p. 31. Na TransAtlantic Slave Trade Database, os navios Maria Segunda, Paquete, Tejo Aventureiro e Virgínia aparecem listados como propriedade de Vergueiro entre 1842 e 1844. Ao todo, estes navios desembarcaram na província do Rio de Janeiro e em Santos cerca de 2.291 africanos ilegalmente escravizados, vindos da baía de Benim, da zona congo-angolana e de Moçambique. Boris Kossoy, Hercule Florence: A descoberta isolada da fotografia no Brasil, $3^{\mathrm{a}}$ ed. rev. ampl., São Paulo: Edusp, 2006.

18 Daniel P. Kidder e James C. Fletcher, O Brasil e os brasileiros, São Paulo: Companhia Editora Nacional, 1941, v. 2, p. 123. 
O sistema de parceria delineou arranjos de trabalho muito distintos do trabalho forçado em turmas, comum entre os homens e mulheres escravizados de Ibicaba. Em Hamburgo, colonos vindos de estados prussianos ou cantões suíços firmavam contratos com a Vergueiro \& Cia., concordando com o pagamento antecipado dos custos de transporte, impostos, moradia e despesas para o estabelecimento inicial na colônia. Os imigrantes deixavam com Vergueiro a responsabilidade de vender a safra de café no mercado e, em vez de um salário, se comprometiam a receber metade da receita líquida de sua colheita após o pagamento anual das despesas incorridas. Todas as dívidas dos colonos eram sujeitas a juros mínimos de 6\% e a duração de seus contratos permanecia em aberto, dependendo da capacidade do colono de reembolsar os patrões. Imigrantes suíços e alemães viajavam para o Brasil em unidades familiares, podendo eventualmente vir a se tornar cidadãos brasileiros naturalizados. ${ }^{19}$

A viagem da Europa a Santos, no litoral paulista, durava quase dois meses. Na década de 1840, ao chegar ao porto brasileiro, os imigrantes eram alojados nos antigos galpões do comércio negreiro enquanto aguardavam o transporte de mula serra acima para Ibicaba. Ao saudar um grupo de imigrantes nas docas de Santos, José Vergueiro disse, certa vez, ao reverendo Fletcher: “eles respiram aqui o ar da liberdade, senhor, - tal como nunca respiraram em sua terra natal”. ${ }^{20}$ Após vários dias em trânsito para Limeira, os colonos se estabeleciam em casas localizadas a cerca de $1 \mathrm{~km}$ de distância da mansão central da fazenda. A Colônia Senador Vergueiro compunha-se, então, de um aglomerado de cabanas de um cômodo com telhados de palha, cercadas por lotes de plantações para a subsistência e campos de café. Segundo o cônsul suíço Carlos Perret-Gentil, que visitou Ibicaba em 1851, os escravizados eram os responsáveis por “preparar

19 Thomas Davatz, Memórias de um colono no Brasil, São Paulo: Livraria Martins, 1941.

20 Kidder e Fletcher, O Brasil e os brasileiros, p. 125. 
novas terras para o assentamento de novos colonos”, incluindo o terreno e a construção de casas para as famílias que chegavam. ${ }^{21}$

Os colonos podiam cultivar alguns alimentos em Ibicaba, mas tinham que comprar todas as demais necessidades básicas na venda da fazenda. ${ }^{22}$ Logo ao chegar em Limeira, eles descobriam que a permissão do diretor da colônia também era necessária para transitar pela cidade ou viajar para longe. Qualquer dívida contraída com a Casa Vergueiro era herdada pelas famílias dos colonos, passando de uma geração para outra em caso de morte. O contrato previa também a possibilidade de transferência do parceiro a outros empregadores, independentemente da sua vontade, uma prática que passou a ser comparada por colonos à revenda de escravizados. Com o tempo, o sistema de parceria provou ser bastante vulnerável a abusos, que iam desde a cobrança excessiva de bens e serviços e violações dos direitos contratuais dos meeiros até o endividamento permanente e a violência física. Na década de 1850, histórias sobre colonos alemães e suíços reduzidos à “escravidão branca” no Brasil tornaram-se comuns na Europa, onde a imprensa costumava publicar cartas de imigrantes que assim explicavam suas condições de trabalho no Brasil. ${ }^{23}$

Embora trabalhassem e vivessem em lados diferentes de Ibicaba, na prática, suíços, alemães e escravizados costumavam se cruzar - seja nas estradas de terra da fazenda ou no terreiro, o grande terraço murado para onde os grãos de café eram lavados, secos e processados. Os colonos colhiam seu próprio café na Colônia, mas trabalhadores escravizados eram

21 Carlos Perret-Gentil, A colônia Senador Vergueiro: considerações de Carlos PerretGentil, cônsul geral da Suíssa no Rio de Janeiro, Santos: Typographia Imparcial de F.M.R. D’Almeida, 1851, p. 37.

22 Em relatório de 1858, o presidente de São Paulo listou as origens étnicas dos colonos de Ibicaba: 227 alemães, 267 suíço-alemães, 41 suíços-franceses, 258 portugueses e 23 belgas. Naquele ano, 25 colônias de parceria existiam na província. Relatório de Abertura da Assembléia Legislativa Provincial, São Paulo, 2 fev. 1858.

23 Eugene Cassidy, "The ambivalence of slavery, the certainty of Germanness: Representations of slave-holding and its impact among German settlers in Brazil, 1820-1889”, German History, v. 33, n. 3 (2015), pp. 367-384; Débora Bendocchi Alves, "Cartas de imigrantes como fonte para o historiador: Rio de Janeiro - Turíngia (1852-1853)”, Revista Brasileira de História, v. 23, n. 45 (2003), pp. 155-184. 
responsáveis por todas as tarefas de processamento, para as quais usavam máquinas a vapor no terreiro. Em Ibicaba, Nicolau Vergueiro aliava gestão paisagística ao controle social de sua força de trabalho: as edificações que cercavam o terreiro garantiam a vigilância dos imigrantes, assim como a esparsa plantação vertical dos pés de café nas colinas permitia a observação constante dos escravizados. Em frente do terreiro, a torre do relógio regulava todos os ritmos de trabalho, alinhando-se às senzalas que lembravam os barracões cubanos. Seguiam-se a elas a casa grande dos Vergueiro, a capela e a casa das máquinas. Esse complexo era o centro da vida econômica e social de todos os trabalhadores em Ibicaba. O cônsul Gentil registrou, por exemplo, ter participado de uma cerimônia mista de casamento na capela, onde um padre convidado celebrara a união de três colonos e dezesseis escravizados. ${ }^{24}$

Figura 2

Escravizados e colonos no terreiro de café na Fazenda Ibicaba, século XIX (ao fundo, vê-se a torre do relógio e um conjunto de senzalas)

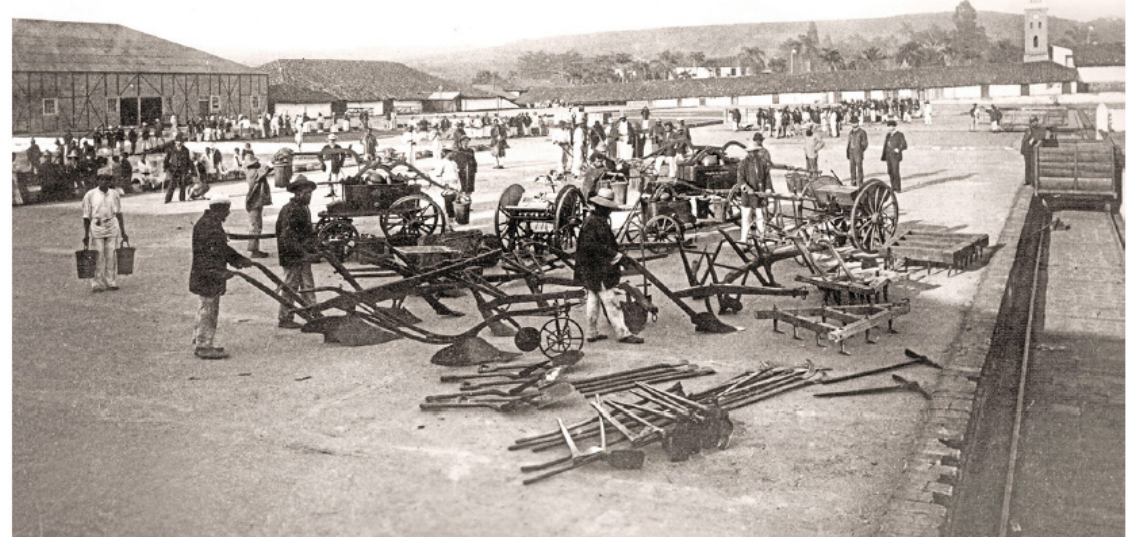

Fonte: Banco de imagens do Carlota Schmidt Memorial Center, Álbum José Vergueiro.

24 Gentil, A colônia Senador Vergueiro, p. 83. 
A estrita disciplina social, restrições à mobilidade, violação de correspondência e a perspetiva de falência total por endividamento contribuíram para radicalizar a atitude de imigrantes em colônias particulares na década de $1850 .{ }^{25}$ Entre os insurgentes de Ibicaba, sobressaiu-se o suíço Thomas Davatz (1815-1888), líder político oriundo da pequena aldeia de Fanas, Cantão dos Grisões, que emigrou para o Brasil em 1854 após assinar um contrato com a Casa Vergueiro em Hamburgo. Atraído principalmente pela promessa de uma vida melhor nas Américas, nos moldes do que ouvia falar sobre os Estados Unidos, Davatz viajou com sua esposa e crianças para Ibicaba em capacidade semi-oficial, portando uma comissão das autoridades cantonais para informar sobre as condições dos colonos suíços no Brasil. Não surpreende, portanto, que, em 1856, ele tenha emergido como o principal porta-voz dos colonos nas negociações com a família Vergueiro. Em agosto daquele ano, as tensões com os administradores de Ibicaba recrudesceram devido à queda acentuada das receitas dos colonos, apesar de uma safra espetacular de café. Suspeitando que Vergueiro estivesse especulando com os preços do produto, os colonos encaminharam reclamações ao cônsul suíço no Rio de Janeiro e escreveram cartas para várias autoridades europeias. Em dezembro, eles se reuniram na residência de Davatz, onde funcionava a escola improvisada da Colônia Senador Vergueiro, e elaboraram uma lista de queixas que incluía um apelo para a abertura de inquérito sobre as condições abusivas de trabalho em Ibicaba. Membros de famílias suíças submetidas ao sistema de parceria acreditavam serem tratadas como "verdadeiros escravos" pelos fazendeiros locais e entregaram sua petição ao sr. João Adolfo Jonas, administrador da fazenda. ${ }^{26}$

25 Historiadores estimam que cerca de 3.500 imigrantes europeus trabalhavam em 30 fazendas em São Paulo. Nicolau Vergueiro era também proprietário da colônia Angélica, a cinco léguas de Ibicaba. Verena Stolke, Coffee Planters, Workers, and Wives: Class Conflict and Gender Relations on São Paulo's Plantations, 1850-1980, London: St Anthony's: Macmillan Series, 1988, p. 3.

26 Davatz, Memórias de um colono, p. 123. 
Na noite de 24 de dezembro de 1856, à medida que se espalhava a notícia do conteúdo crítico da referida petição, Nicolau Vergueiro chamou Davatz a seu escritório na casa grande. O sr. Jonas serviu de intérprete na reunião, que contou também com a presença de Luís Vergueiro, filho e tesoureiro do senador, além do médico da colônia, dr. Gattiker. Davatz mostrou ao fazendeiro uma lista de reivindicações assinada por 85 colonos de Ibicaba e mencionou que esperava que o Consulado Suíço abrisse uma investigação sobre as violações de contratos na fazenda. Colonos que esperavam do lado de fora da casa de Vergueiro logo presumiram que Davatz estava sob a mira de uma arma e chamaram outros temendo a prisão iminente do companheiro. Homens e mulheres munidos de armas de fogo e ferramentas de trabalho se levantaram em Ibicaba na tentativa de salvar seu líder. Naquela véspera de Natal, foram disparados dois tiros, mas não houve confronto direto com a família Vergueiro. O movimento sobreviveu no desafio permanente que os colonos apresentaram no seu cotidiano de trabalho, pois continuavam a exigir mudanças contratuais e a andar armados.

Convencido de que toda a mão de obra de Ibicaba estava em rebelião, o senador Vergueiro solicitou ao governo imperial o envio de tropas para Limeira e demitiu Davatz, dando-lhe trinta dias para deixar a propriedade. Como este se recusou a sair, as tensões continuaram a aumentar até que o consulado da Suíça enviou o dr. Diethelm juntamente com o dr. J. C. Heusser, representante de seis municípios suíços, para iniciar um inquérito em janeiro de 1857. No mês seguinte, Davatz ainda falava em armar os colonos e bradava que os suíços tomariam toda a província de São Paulo, se necessário. Vergueiro considerou fantasia as expectativas dos colonos de que o imperador Pedro II iria lhes conceder terras, o que descrevia como plano dos revoltosos de estabelecer uma República Suíça em São Paulo. Muitos suíços, porém, aguardavam apenas uma resposta favorável do Rio de Janeiro para deixar Ibicaba. Alguns esperavam que autoridades brasileiras saíssem em sua defesa, já que Vergueiro pertencia à oposição liberal; outros subscreviam as ideias de outro imigrante suíço, 
J. J. Oswald - um professor de piano residente na capital São Paulo. ${ }^{27}$ O senador Vergueiro tinha-o como o principal inimigo dos fazendeiros, já que "fora obrigado a sair da Suíça por comunista, fora para a Argélia e não achando aí modo de vida sem trabalho, veio para o paciente Brasil”. Oswald trocava cartas com os suíços de Limeira e Rio Claro e, ao que parece, as enviava à Suíça "por meio de seu patrício Leiden, fabricante de cerveja no Rio de Janeiro”. ${ }^{28}$

Nicolau Vergueiro atribuiu a revolta em Ibicaba "às escolhas bastante prudentes que os municípios suíços fazem da escória de sua população para auxiliar em sua imigração”. ${ }^{29}$ Daí as acusações de adesão ao comunismo, ideologia que políticos e proprietários brasileiros associavam à revolução de 1848 na França e aos "mendigos da Europa”. ${ }^{30}$ Na assembleia provincial de São Paulo, por exemplo, o tema não raro aparecia em debates sobre o protesto negro, já que o perigo de rebelião invocava sempre outras versões de subversão da ordem social. Em março de 1855, o assunto surgiu na discussão de um projeto para a taxação dos escravizados dos conventos paulistas. O deputado Manoel Eufrásio defendeu a proposta como meio de eliminar grandes fazendas “onde está um grande número de escravos pertencentes a essas ordens; são braços inativos que, acoutando os escravos de outras fazendas, e mesmo oferecendo maus exemplos concorrem grandemente para a desmoralização da escravatura circumvizinha”. De acordo com Eufrásio, 1.600 trabalhadores escravizados de conventos continuavam ociosos e o imposto forçaria os

27 Davatz, Memórias de um colono, p. 123.

28 ANRJ, SJ, IJ1-512, Carta do Senador Vergueiro ao Vice-Presidente de São Paulo, Antônio Roberto de Almeida, 10 fev. 1857.

29 ANRJ, SJ, IJ1-512, Carta do Senador Vergueiro ao Vice-Presidente de São Paulo.

30 Na sessão do Parlamento Brasileiro de 28 de agosto de 1860, o sr. Martinho de Campos argumentou que os "mendigos da Europa” passavam melhor que os pobres brasileiros: "Nós vemos que o socialismo suplantado, vencido e batido, depois de suas vitórias efêmeras de 1848, veio ter o seu triunfo completo no nosso belo país. Os Srs. Ministros de diversos gabinetes entre nós inventaram uma maneira decente de promover o triunfo do socialismo, inventaram os tais núcleos de colonização”. Anais do Parlamento Brasileiro, Rio de Janeiro: Typographia Imperial e Constitucional de J. Villeneuve e C., 1860, p. 267. 
frades a colocá-los para trabalhar ou os vender a fim de pagarem o imposto. Parte da oposição, o deputado Ricardo Corrêa qualificou o projeto como uma tentativa de confiscar os bens da classe clerical no país, ou seja: uma verdadeira “doutrina do socialismo”. O deputado Hipólito foi ainda mais longe ao descrever as propriedades dos frades escravistas: "em socialismo vivem eles; são os maiores comunistas do mundo”. ${ }^{31}$ Socialismo e comunismo adornavam a retórica parlamentar como verdadeiras ameaças ao direito de propriedade e à moral dos trabalhadores negros.

A família Vergueiro assim se referia a colonos como Oswald e Davatz: comunistas! O desejo de posse coletiva da terra expresso por eles apenas aumentava os rumores sobre a existência de uma sociedade secreta comunista com sede na corte imperial. O marquês de Olinda, por exemplo, ao caracterizar a revolta de 1856 como uma insurreição encabeçada por indivíduos mal-intencionados e pouco afeitos ao trabalho, explicou: "se o governo anuísse a lhes dar terras gratuitamente e a fazer-lhes as concessões que exigiam o exemplo seria funestíssimo: uma sublevação geral apareceria em todas as colônias de contratos de serviços, qualquer que fosse a forma desses contratos”. ${ }^{32}$

Thomas Davatz finalmente embarcou para a Europa em 13 de março de 1857, levando consigo a lembrança dos conflitos trabalhistas que virariam material para seu livro, Memórias de um colono no Brasil, editado em Chür em 1858. ${ }^{33}$ Na obra, Davatz reuniu a perspetiva crítica dos colonos, acusando diretamente os fazendeiros brasileiros de recorrerem à “escravidão branca” após a cessação do tráfico de africanos para o país. Escrevendo para um público europeu, Davatz apelou às sensibilidades abolicionistas no Velho Continente ao comentar a sorte dos suíços:

31 Correio Paulistano, São Paulo, 25 mar. 1855, p. 2 ש.

32 Correio Paulistano, 25 mar. 1855, p. 2.

33 Rafael Pereira da Silva, "Modernismo, historiografia e sociabilidade intelectual: apontamentos sobre o quinto volume da coleção Biblioteca Histórica Brasileira (1931-1940)”, História (São Paulo), v. 31, n. 2 (2012), pp. 310-337; Ana Luiza Martins e Ilka Stern Cohen, O Brasil pelo olhar de Thomas Davatz (1856-1858), São Paulo: Atual, 2000. 
Será exagero [...] dizer-se que os colonos se acham sujeitos a uma nova espécie de escravidão, mais vantajosa para os patrões do que a verdadeira, pois recebem os europeus por preços bem mais moderados do que os dos africanos [...], sem falar no fato do trabalho dos brancos ser mais proveitoso que o dos negros? [...] E essa escravidão pode mesmo ser empreendida sob o amparo da lei. ${ }^{34}$

Em alemão, o título original da obra de Davatz é "Um apelo e alerta aos amigos e autoridades dos estados aos quais os colonos pertencem"; era, portanto, um manifesto contra a "febre da emigração" que pretendia inspirar camponeses europeus pobres a evitar o Brasil a todo custo. Davatz descreveu os proprietários de terras como Vergueiro como classe cega à ideia de contrato e ao tipo de liberdade buscado pelos suíços no Brasil. Segundo ele, com olhos treinados no comércio de escravizados, os fazendeiros ofereciam aos colonos "o mesmo desprezo" reservado aos negros. ${ }^{35}$ Apesar de invocar a ideia da escravidão branca para definir o tipo de coerção sofrida pelos imigrantes no Brasil, Davatz endossava a explicação bíblica do cativeiro negro, justificando a "subjugação inata dos africanos aos brancos” como resultado da maldição lançada por Noé sobre os descendentes de Cã. ${ }^{36} \mathrm{O}$ mestre-escola retratou os "habitantes negros do Brasil” como pessoas conscientes “de serem vítimas” e admitiu que, se não fosse por tal disposição à submissão, "seria fácil para eles, dado o seu número considerável, se vingar de seus traficantes e opressores.

34 Davatz, Memórias de um colono, p. 180.

35 Davatz, Memórias de um colono, pp. 234, 239. Até Mário de Andrade descreveu a sorte dos colonos suíços desta forma, ao comentar o livro de Davatz: "Os livres suíços que vinham para Ibicaba volupiados pelas lendas duma terra de oiro, garantidos por contratos aperitivantes de arrendamento à meia e trato melhor que os das aldeias nevadas, encontravam era uma legítima escravidão”. Diário Nacional, São Paulo, 9 ago. 1931, p. 7.

36 Alguns colonos de língua alemã também se tornaram senhores de escravos no Brasil. Sobre o apagamento da memória da escravidão no Rio Grande do Sul, ver: Loraine Slomp Giron e Roberto Radunz. "Invisíveis: negros nas memórias dos brancos”, Revista Brasileira de História e Ciências Sociais, v. 4, n. 7 (2012), pp. 143-161. 
No entanto, que eu saiba, isso nunca aconteceu, pelo menos em grande escala”. ${ }^{37}$

Relatos como o de Davatz sobre os abusos do sistema de parceria acabaram levando governos estrangeiros a proibir de fato a emigração para o Brasil. Como vemos, duas visões muito diferentes de colonização estavam em conflito na década de 1850: enquanto os parceiros suíços se viam como camponeses independentes trabalhando pela posse da terra, os Vergueiro os tomavam como mão de obra dependente, para ser monitorada de perto - uma espécie de trabalhador não-escravo ainda muito distante dos ideais de trabalho assalariado moderno. ${ }^{38}$ Em 2 de dezembro de 1857, o governo da Confederação Suíça dirigiu uma carta ao ministério do Império sobre as queixas dos colonos de Ibicaba, pedindo que fossem eles "livres da escravidão e transportados para terras do Estado; declarando que alguns cantões têm julgado dever tomar medidas para embargar a emigração, até uma nova ordem de coisas, sendo provável que tais medidas sejam generalizadas”. ${ }^{39}$ Em 1859, após debates parlamentares sobre maus-tratos a colonos alemães, a Prússia aprovou o Edito de Heydt proibindo toda propaganda e subsídios para emigração para o Brasil. ${ }^{40}$

\section{Colonos e culturas políticas negras}

As expectativas que Thomas Davatz nutria a respeito dos escravizados, de que se juntassem à revolta de 1856, não constam em seu livro. Talvez

37 Davatz, Memória de um colono, p. 61.

38 Celso Furtado chamou atenção para a mentalidade de fazendeiros acostumados à lógica escravista. Eles consideravam imigrantes livres como "elementos de resistência” perigosos em um "sistema de precaução e vigilância” que visava combater o ativismo negro. Celso Furtado, Formação econômica do Brasil, Rio de Janeiro: Editora Fundo de Cultura, 1959, p. 142.

39 Correio da Tarde, Rio de Janeiro, 2 jul. 1858 ש.

40 O medico alemão Robert Avé-Lallemand visitou o Brasil na década de 1850 e corroborou a narrativa de Davatz sobre os maus tratos de alemães na colônia de Mucuri em Minas Gerais. Robert Avé-Lallemant, Viagem pelo Norte do Brasil no ano de 1859, Rio de Janeiro: Instituto Nacional do Livro; Ministério da Educação e Cultura, 1961. 
ele tenha escolhido deixar de fora do registro escrito informações que certamente poderiam ter levado outros colonos à prisão no Brasil. O que sabemos vem de depoimentos colhidos ainda em Ibicaba pelo polonês H. Ulmann em 1856. As estratégias de Davatz contra os Vergueiro, no entanto, soavam familiares a escravizados experientes na organização de quilombos e ávidos observadores do avanço desigual da emancipação pelas Américas. Uma vez ameaçado de expulsão da Colônia Senador Vergueiro, o mestre-escola planejava deixar para trás dívidas pendentes e conduzir todos os imigrantes das colônias locais para um pedaço de terra virgem que pudesse ser defendido de invasão, uma espécie de comunidade fortificada. Além disso, Davatz esperava a coadjuvação de forças navais francesas e inglesas na luta pela abolição de todas as formas de trabalho forçado no Brasil. ${ }^{41}$

Em 1857, moradores de Limeira também descreveram a Revolta dos Parceiros como um movimento articulado entre várias colônias locais de imigrantes "para formar uma independência, em uniformidade com os escravos". ${ }^{42}$ Em Rio Claro, a Câmara Municipal argumentou que era inegável que "colonos suíços da colônia - Senador Vergueiro - se organizaram sob a direção de uma sociedade secreta, se armaram e se corresponderam com outras colônias, contando não só com a cooperação delas, mas também com a de escravos e brasileiros descontentes; eles falam sobre a formação de um Estado Livre”. ${ }^{43}$ Essas versões, é verdade, são fruto tanto dos fatos quanto do medo de que rebentasse uma revolta escrava sem precedentes. A elite paulista tratava os parceiros suíços como mais uma encarnação da ameaça estrangeira à escravidão brasileira em tempos de avanço do pensamento abolicionista no mundo. Dessa forma, os colonos seriam como mãos "inteligentes" que ocultamente guiavam os negros à rebelião em desafio às leis do país.

41 ANRJ, SJ, IJ1-512, Cópia da carta de H. Ullmann ao Senador Vergueiro.

42 Brasil, Annaes do Parlamento Brazileiro, Tomo 4, Rio de Janeiro: Typographia Imperial e Constitucional de J. Villeneuve e Comp., 1857, p. 165.

43 Brasil, Annaes do Parlamento Brazileiro, p. 165. 
Uma postura analítica alternativa, entretanto, nos permite ir além do maniqueísmo dos fazendeiros e políticos do oeste paulista. Em vez de tentar provar a todo custo que escravizados estavam envolvidos na revolta de 1856, como queriam as autoridades policiais do Império, talvez caiba perguntar por que tantos de seus contemporâneos consideraram factível a ideia de que escravizados e colonos estariam planejando um levante geral - só assim podemos notar como a revolta expôs o desenvolvimento de novas formas de consciência política entre populações marginalizadas no Brasil, mesmo enquanto a escravidão ainda prosperava. Os colonos demonstraram em palavra e ação que, em vez da criação de um mercado de trabalho livre, a parceria na cafeicultura mais parecia o primeiro passo em direção à servidão por dívida. Enlaçados nas profundezas dos esquemas internacionais de migração, imigrantes suíços e alemães descreveram sua falta de poder e influência nas negociações com os proprietários brasileiros como outra forma de escravidão. Eles se ressentiam, especialmente, da natureza extra-econômica da disciplina de trabalho em Ibicaba, onde, aos colonos, era negado o direito à ação coletiva sob os termos específicos ditados por uma sociedade escravocrata.

Figura 3

Escravizados no eito, Fazenda Ibicaba, século XIX

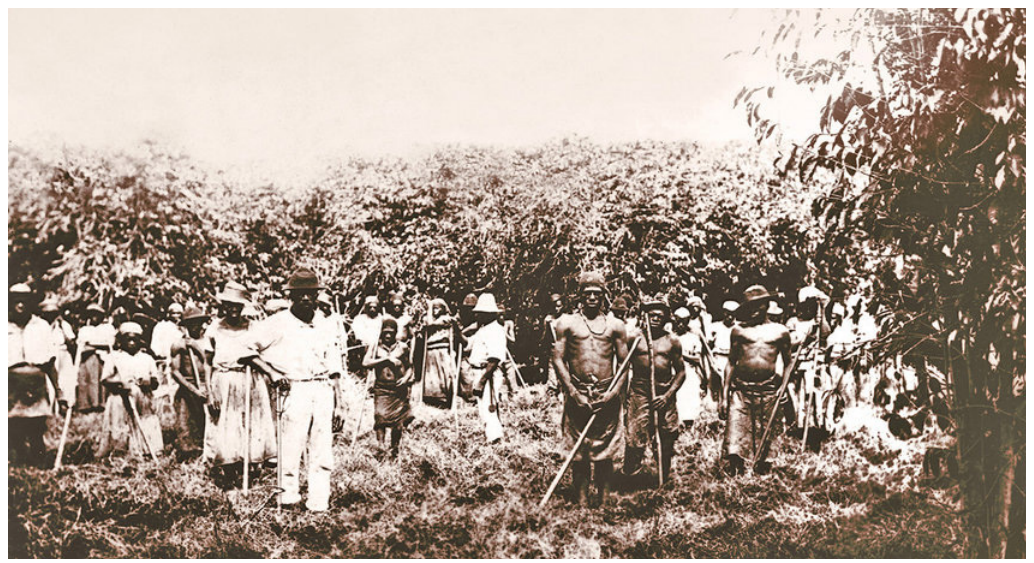

Fonte: Banco de imagens do Carlota Schmidt Memorial Center, Álbum José Vergueiro. 
Comunidades negras, por sua vez, ouviram com cuidado as críticas dos imigrantes à opressão em todas as suas formas. Os escravizados paulistas já conheciam de perto o abolicionismo inglês e o republicanismo antes de tais temas virem à tona em Ibicaba, justamente por partilhar de uma tradição rebelde para a qual o internacionalismo era elemento central. ${ }^{44}$ A alfabetização geopolítica de negros livres e cativos concedia sentidos diaspóricos à liberdade ao ligar o status dos escravizados brasileiros ao destino de outras comunidades negras nas Américas. Assim, por exemplo, cativos se rebelaram ao longo do século XIX ao ouvir falar da Revolução Haitiana, da formação de repúblicas latino-americanas, da Guerra Civil nos Estados Unidos ou da campanha britânica contra o tráfico. ${ }^{45}$ Em 1856, frustrados com as chances de se tornarem livres no Brasil imperial, os escravizados do senador Vergueiro pareciam interessados em buscar sua emancipação no interior de uma nova entidade política, talvez semelhante a um quilombo fortificado ou à colônia agrícola que os suíços solicitaram ao governo imperial. Em assim fazer, eles não agiam como massa de manobra nas mãos de espertos imigrantes europeus; eram participantes voluntários de uma aliança com colonos que condenavam a escravidão e compartilhavam a crença no apoio francês e britânico à abolição no Brasil. Senão vejamos.

Ideias sobre alianças com potências estrangeiras circulavam em comunidades escravizadas havia anos em razão de contato com colonos, experiências negras do tráfico ilegal, notícias de jornais e encontros fortuitos com forasteiros. Em setembro de 1848, por exemplo, pouco

44 David Harvey, “The Sociological and Geographical Imaginations”, International Journal of Politics, Culture, and Society, v. 18 (2005), pp. 211-255; Katherine McKittrick, Demonic Grounds: Black Women and the Cartographies of Struggle, Minnesota: University of Minnesota Press, 2009.

45 Ver, dentre outros, João José Reis e Flávio dos Santos Gomes, "Repercussions of the Haitian Revolution in Brazil, 1791-1850” in David Patrick Geggus e Norman Fiering (eds.), The World of the Haitian Revolution (Bloomington: Indiana University Press, 2009), pp. 284-315; Gomes, A hidra e os pântanos; Thiago Leitão de Araújo, "Desafiando a escravidão: fugitivos e insurgentes negros e a política de liberdade nas fronteiras do Rio da Prata: Brasil e Uruguai (1842-1865)”, Tese (Doutorado em História Social), Universidade Estadual de Campinas, Campinas, 2016. 
mais de um ano após a fundação da Colônia Senador Vergueiro, rumores sobre uma insurreição negra chegaram ao conhecimento de José Vergueiro durante uma visita à vila da Constituição (hoje Piracicaba), na província de São Paulo. Tendo ouvido falar que franceses “incitavam” escravizados a se rebelar, Vergueiro decidiu voltar à Ibicaba para interrogar alguns de seus colonos. Dois alemães residentes na Colônia revelaram que Alberto de Neubern, ex-morador do lugar, vinha convidando moradores

para influírem numa insurreição d'escravos, que Unidos/ como ele dizia/ com Índios dos quais ele tinha conhecimento, oferecia vantagens não pequenas às suas vistas cobiçosas: que ele um dia apresentar-se-ia à testa desta gente, e que então seria rico. ${ }^{46}$

Os alemães revelaram ainda que "desde o Rio de Janeiro até aquelas paragens”, Neubern "havia visitado todas as fazendas, e conhecia toda a escravatura; que no distrito da Limeira, tinha igualmente relações com todos os estabelecimentos”. ${ }^{47}$

Alberto de Neubern era um veterano do exército francês na África que havia vindo da Alemanha para o Brasil. Constava que ele havia deixado Ibicaba sem acertar suas dívidas com a Casa Vergueiro e que, na companhia de outro estrangeiro não nomeado, mantinha contato com senzalas de Limeira e Rio Claro. De acordo com José Vergueiro, seu companheiro era também alemão, tendo "andado muitos anos pelos Estados Unidos, é hebreu de religião, baixo, muito louro, fisionomia agradável, vivo em sua conversação, e fala francês e inglês. Tenho-o encontrado no interior, sempre armado com uma clavina”. Convencido de que "o geral da escravatura está iniciada da ideia geral de Liberdade”, Vergueiro pediu ao chefe de polícia em 1848 que incentivasse todos os fazendeiros locais a colocarem seus estabelecimentos sob "estado de

46 APESP, Secretaria de Polícia da Província, CO 2452, Carta de José Vergueiro ao chefe de polícia Francisco Lourenço de Freitas, 7 set. 1848.

47 APESP, Carta de José Vergueiro ao chefe de polícia Francisco Lourenço de Freitas. 
sítio" ${ }^{48}$ Três escravizados foram presos e interrogados na ocasião, mas nada revelaram sobre a revolta que se esperava tomar o oeste paulista.

$\mathrm{O}$ perigo era iminente porque às comunidades negras da região não escapou a importância de correntes abolicionistas europeias durante a década de 1840. Em 1845, a Grã-Bretanha acelerou o ritmo das apreensões de navios negreiros brasileiros através da passagem do Ato Aberdeen, que complementava outras medidas restritivas como a proibição da posse de escravizados por súditos ingleses vivendo no exterior. ${ }^{49}$ Lord Aberdeen, então secretário do exterior britânico, insistia que os traficantes brasileiros deveriam ser tratados como piratas e assim alimentou a retórica militante que orientaria a campanha britânica na década seguinte. O governo brasileiro considerou o Ato de 1845 como medida hostil em tempos de paz e protestou em nome da soberania nacional; no entanto, a incapacidade do império brasileiro de cumprir a lei de 1831 e estancar o contrabando de africanos mantinha o país numa posição fraca, já que a crítica à interferência britânica se traduzia na impunidade de traficantes de africanos e no endosso silencioso do direito costumeiro dos senhores ao trabalho de africanos escravizados ilegalmente..$^{50}$

O debate sobre a extinção do tráfico influenciou profundamente as culturas políticas negras no país. Ainda que incapaz de precipitar o fim da escravidão e conduzido por um Gabinete conservador que em tudo aliviou o golpe que a extinção de tal comércio representava aos interesses dos proprietários, o processo sinalizou aos escravizados a existência de uma brecha em estruturas de dominação. O sentimento antibritânico que se desenvolveu no Brasil como desafio à implantação de tratados bilaterais popularizou a imagem da Inglaterra como aliada e protetora de africanos e

48 APESP, Carta de José Vergueiro ao chefe de polícia Francisco Lourenço de Freitas.

49 Leslie Bethell, The Abolition of the Brazilian Slave Trade: Britain, Brazil and the Slave Trade Question, 1807-1869, Londres, Nova York: Cambridge University Press, 1970; Richard Huzzey, Freedom Burning: Anti-Slavery and Empire in Victorian Britain, Ithaca: Cornell University Press, 2012.

50 Chalhoub, A Força da Escravidão; Thâmis Parron, A política da escravidão no Império do Brasil: 1826-1865, Rio de Janeiro: Civilização Brasileira, 2011. 
seus descendentes. ${ }^{51} \mathrm{Na}$ prática, ao planejar rebeliões que contavam com suposto apoio inglês, comunidades escravizadas ressignificaram a diplomacia inglesa no Brasil, tornando-a de fato abolicionista. Assim também fizeram com a França em 1848. No contexto da onda revolucionária que derrubou a monarquia francesa, o novo governo republicano passou naquele ano um decreto abolindo a escravidão em suas colônias, alçando a França ao patamar de aliada potencial dos negros no mundo atlântico.

$\mathrm{Na}$ contramão da resposta das elites brasileiras às diplomacias inglesa e francesa em 1848, conspirações escravas eclodiram nas províncias do Rio de Janeiro, São Paulo e Minas Gerais. ${ }^{52}$ Em Lorena, o "suíço ou francês” (provavelmente suíço de língua francesa) Jacques Troller, homem republicano e amigo do fazendeiro Antônio Gaspar Martins Varanda, foi preso por pregar “os princípios abolicionistas da escravidão” entre os escravizados. Troller lia os jornais do dia na frente de cativos letrados como Agostinho, pajem de Varanda, citando com frequência a experiência revolucionária do Haiti. Preparados para se levantar durante os festejos de São João, no entanto, os escravizados de Varanda apostavam menos no exemplo do Haiti do que numa eventual intervenção dos ingleses, "visto

51 Essa ideia ganhou força no Brasil especialmente através do ativismo dos africanos livres, homens e mulheres resgatados no tráfico ilegal em cumprimento a tratados bilaterais entre Brasil e Inglaterra. Com a promessa de emancipação após catorze anos de trabalho tutelado pelo Estado ou por particulares, eles constituíram uma categoria especial de trabalhadores não-livres no Brasil. Seus períodos de "aprendizado" geralmente ultrapassavam o esperado e alguns viveram em condições semelhantes à escravidão. Sendo assim, muitos buscaram proteção contra a reescravizacão em consulados britânicos, aconselhando-se com diplomatas ingleses em casos de maus-tratos e remoção forçada para a África. Mamigonian, Africanos livres.

52 Sobre as rebeliões escravas de 1848, ver também: Sidney Chalhoub, Visões da liberdade: as últimas décadas da escravidão na Corte, São Paulo: Companhia das Letras, 1990, pp. 186-212; Robert W. Slenes, “A árvore de Nsanda transplantada: cultos Kongo de aflição e identidade escrava no Sudeste brasileiro (século XIX)” in Douglas Cole Libby e Júnia Furtado (orgs.), Trabalho livre, trabalho escravo: Brasil e Europa, séculos XVIII e XIX (São Paulo: Annablume, 2006), pp. 273-314; Dale Graden, Disease, Resistance, and Lies: The Demise of the Transatlantic Slave Trade to Brazil and Cuba, Baton Rouge: Louisiana State University Press, 2014. 
que o Brasil acha-se bastante empenhado com aquela Nação da Inglaterra, e tanto mais por haver cessado o tráfico da escravatura”. ${ }^{53}$

Em Indaiatuba, a $72 \mathrm{~km}$ de Limeira, comunidades negras organizaram uma rebelião para o dia 7 de setembro de 1848, associando um possível decreto da família real brasileira às notícias da abolição em colônias francesas e expectativas de apoio militar inglês. Enquanto trabalhava nas plantações de café do padre Bento Dias Pacheco, Francisco, mais conhecido como Tático, ouvira "que os Franceses, ou Ingleses /o que ele não estava bem certo" haviam de vir ajudar aos cativos "porque eles querem que nós todos sejamos forros”.${ }^{54} \mathrm{~A}$ conspiração gerou a prisão de diversos cativos que confessaram acreditar que o Brasil havia um dia de virar território inglês. Em novembro de 1848, os rumores de insurreição ainda não haviam desaparecido em Campinas, apesar da ferrenha repressão organizada pelo chefe de polícia de São Paulo. Da corte imperial vinham, também, notícias de rebeliões em massa, não raro lideradas por africanos e baseadas na logística fornecida por associações religiosas. Ao descrever o clima político na província, porém, o presidente Vicente Pires da Motta culpou os senhores pela insubordinação de seus cativos. Esse era um expediente comum entre autoridades brasileiras que preferiam ressaltar a falta de disciplina nas fazendas ou tentativas de "sedução" por forasteiros a reconhecer a complexa imaginação política de trabalhadores escravizados. Pires da Motta assim descreveu o cotidiano da escravidão paulista que dava alento às conspirações negras de 1848:

não é tratando-os com desumanidade e brutalmente, que não é exigindo deles serviços superiores às forças humanas, sem lhes dar tempo para o necessário descanso; subministrando-lhes maus e escassos alimentos,

53 Carta de Francisco Lourenço de Freitas ao Presidente de São Paulo, Domiciano Leite Ribeiro, 8 jun. 1848, apud Marcos Couto Gonçalves, "Papéis Avulsos: A insurreição dos escravos no Vale do Paraíba”, Revista Acervo Histórico, v. 3 (2005), p. 70. Ver também: Mamigonian, Africanos livres, pp. 216-223.

54 APESP, Secretaria de Polícia da Província, CO 2452, Acareação de Tático, José e Joaquim em Indaiatuba, 4 set. 1848. 
e apenas um péssimo vestuário sempre imundo e esfarrapado, que nem lhes cobre a nudez, e nem abriga do frio; que não é condenando-os a castigos atrozes, arbitrários, caprichosos e sem nenhuma proporção com as faltas; que não é saciando-os de desgostos e insultos, e tornando-lhes a vida insuportável e odiosa, que hão de ganhar a afeição dessa classe miserável, e conseguir que não nutram desejos de insurreição. Cumpre que façam compreender aos Senhores, que se não querem escutar as vozes da Religião e da humanidade, ao menos não cerrem os ouvidos à voz do próprio interesse que lhes grita, que tratem aos escravos como criaturas humanas. ${ }^{55}$

A conjuntura explosiva que teve início em 1848 pode nos ajudar a contextualizar os rumores generalizados de uma rebelião negra em Limeira, Rio Claro, Constituição e Campinas em 1857. Outras conspirações emergiram em Bananal em 1853 - seguindo-se ao desembarque de diversos africanos ilegalmente escravizados em Bracuí - e em Taubaté e Pindamonhangaba, onde escravizados se levantaram durante a Páscoa de 1854. ${ }^{56}$ A leitura que a família Vergueiro fez da Revolta dos Parceiros se espelhava em décadas de experiência no combate ao ativismo cativo que avançava na esteira do abolicionismo atlântico. ${ }^{57}$ Ao reprimir os colonos, José Vergueiro requisitou que tropas também fossem mandadas para Campinas, “onde se estima que o número de escravos supere os vinte mil e estes já tentaram várias vezes organizar algum movimento”:

55 APESP, Secretaria de Agricultura, Comércio e Obras Públicas da Província de São Paulo, Imigração e Colonização (1854-1896), cx. C07213, Vicente Pires da Matta ao Chefe de Polícia de São Paulo, 8 nov. 1848.

56 Martha Abreu, “O caso do Bracuhy” in Hebe Mattos e Eduardo Schnoor (orgs.), Resgate: uma janela para os oitocentos (Rio de Janeiro: TopBooks, 1995), pp. 165-195; Jornal do Commercio, 6 jun. 1854.

57 Correspondência dos colonos era corriqueiramente violada por administradores de Ibicaba que agiam em conjunto com o correio de Limeira. Davatz menciona que a Casa Vergueiro também empregava escravizados em esquemas para interceptar cartas dos suíços, já que estes eram os mensageiros entre Limeira e Ibicaba. Davatz, Memória de um colono, p. 178. 
Darvatz [sic] seu chefe é homem atuário, de suma autoridade, sangue frio, e de educação Jesuítica e pregam aos seus que se acha de combinação com altos personagens, que o Brasil vai ser invadido por forças Europeias, a exemplo do que os Estados Unidos tem feito, e que nessa corte já se acham numerosos e avultados vasos de guerra esperando apenas o momento, o brado dado pelos colonos dessa Província para desembarcarem e prestarem-lhes todo o auxílio, em fim não mais longe, tem distribuído entre si terrenos, e plantações das diversas fazendas, e fanatizados, como se acham, acreditam nas promessa de seu chefe.

Declaram que contam com o apoio firme da escravatura, que se unirá a eles apenas dado o grito da liberdade, e que além disso chamaram a si porção de emissários descontentes oferecendo a um os mais altos empregos dessa República que imaginam. ${ }^{58}$

Nicolau, José e Luís Vergueiro jamais foram capazes de admitir que não tinham o poder político para impor o tipo de exploração do trabalho necessária para tornar lucrativa e segura sua colônia de parceria em Ibicaba. Aos escravizados insatisfeitos, somaram colonos insubmissos e tiveram de lidar com o desejo comum de seus trabalhadores de bradar “o grito da liberdade”. A expectativa escrava de apoio britânico à abolição nunca desapareceu das fazendas de café paulistas. No final de 1862, os cativos novamente se agitaram ao ouvir falar sobre o bloqueio naval inglês ao porto do Rio de Janeiro. Em Taubaté, Pindamonhangaba e Caçapava, autoridades relataram que os escravizados, "aconselhados pelos Colonos, tratavam de se amotinar” na noite do dia 24 para o dia 25 de dezembro. ${ }^{59}$ Em março de 1863, em meio à repercussão da Questão Christie - que agitou o debate público no oeste paulista e rebelou escravizados em Campinas -,

58 ANRJ, SJ, IJ1-512, Carta de José Vergueiro a José Nabuco de Araújo, 10 fev. 1857. O que José Vergueiro interpretou como um plano suíço para formar um estado livre no Brasil provavelmente se referia a um pedido feito por Davatz ao cônsul suíço para o estabelecimento de uma colônia independente na província do Rio Grande do Sul.

59 APESP, Secretaria de Polícia da Província, cx. 2.499, Benjamin da Cunha Bueno, delegado de Pindamonhangaba, ao Chefe de Polícia de SP, 22 dez. 1862. 
os cativos de Ibicaba novamente planejaram ir à forra. Um morador de Limeira denunciou às autoridades que o administrador alemão da Colônia Senador Vergueiro havia proclamado "a liberdade dos escravos, deu vivas aos Ingleses, dizendo que estes em breve os viriam libertar, e aconselhou-lhes que não trabalhassem mais para o dono do Estabelecimento pois que eles eram tão livres como os seus Senhores”. ${ }^{60}$ Depois do jantar, Benedito, escravo de Joaquim Policarpo Aranha, foi preso em Campinas e contou os detalhes de uma conversa em que falara sobre revolução com Benedito Taques em sua casa de comércio:

indo no Domingo antes do Carnaval exigir novamente o seu dinheiro, o dito Benedito perguntou-lhe se não sabia das novidades que haviam, e nessa ocasião contou a ele respondente que estando na Aparecida ouvira ler uma folha em que se dizia que os Ingleses tinham exigido uma grande soma de dinheiro de todos os Senhores de Escravos, e que quando esses não dessem este dinheiro, que eles fariam uma revolução para darem liberdade aos Escravos, por isso que os mesmos Ingleses tinham uma Princesa que já tinha vinte e um anos e que não podia ser batizada sem que todos os Escravos fossem libertados.

Enquanto populações escravas se reuniam para decifrar as implicações da ruptura de relações diplomáticas entre Brasil e Inglaterra em 1863, seus senhores buscavam coadjuvar o governo imperial caso uma guerra eclodisse entre os dois países. Ofendido pela "inqualificável agressão da legação inglesa na Corte, a nossa Nacionalidade”, José Vergueiro ofereceu as oficinas de Ibicaba para conserto do armamento nacional em desuso. Tomado por espírito patriótico, ele também solicitou apoio oficial para formar um Corpo de Voluntários em Santos, composto

60 APESP, Secretaria de Polícia da Província, cx. 2.500, Luis José de Sampaio a Vicente Pires da Matta, 17 mar. 1863. 
por brasileiros pobres e estrangeiros que, em sua opinião, eram a classe mais adequada para se engajar num eventual conflito com a Inglaterra. ${ }^{61}$

Enquanto escravizados se inquietavam por todo o oeste paulista, histórias sobre abusos físicos de colonos alemães continuavam a circular em jornais brasileiros e estrangeiros. Em carta publicada no Correio Paulistano, datada de 23 de fevereiro de 1864, "um limeirense” queixou-se longamente da crueldade do administrador alemão de Ibicaba, que havia se recusado a cumprir um mandato apresentado pelo oficial de justiça local pelo crime "de ter surrado a chicote um homem livre", depois levado ao tronco da propriedade. Chamando a atenção da família Vergueiro, o autor denunciava as desordens recorrentes na fazenda "onde mata-se, fere-se e pratica-se todos os atos de maior cinismo sem que as autoridades possam intervir, e nem providenciar". ${ }^{62}$

A Colônia Senador Vergueiro nunca se recuperou totalmente da crise de 1856 e das dificuldades subsequentes em relação ao recrutamento de colonos na Europa. Em 1865, a Casa Vergueiro hipotecou as fazendas Ibicaba e Angélica com todos os escravizados para adquirir um empréstimo do Banco do Brasil. Quando Nicolau Vergueiro morreu, em 1859, seu filho José Vergueiro assumiu a gestão de Ibicaba e à medida que os problemas financeiros se multiplicaram, ele acabou se desiludindo com a imigração patrocinada por particulares. Ainda em 1865, a Vergueiro \& Cia. declarou falência e ofereceu parte da produção de Ibicaba nos próximos anos como garantia da dívida. Constava, então, que a propriedade tinha "cerca de um milhão e 400 mil pés de café, que podem produzir para mais de 100 mil arrobas de café, costeada por uma população agrícola de 1.100 almas entre colonos e escravos”, enquanto a Fazenda Angélica, em Rio Claro, possuía plantações capazes de produzir cerca de trinta mil arrobas de café atendidos também com trabalhadores colonos e escravizados. ${ }^{63}$ Em 1870,

\footnotetext{
61 APESP, Correspondência dos Consulados, CO6122, José Vergueiro a Vicente Pires da Matta, 19 jan. 1863.

62 Correio Paulistano, 4 mar. 1864, p. 3 ש.

63 Diário de São Paulo, 16 jan. 1868, p. 1 ש.
} 
José Vergueiro passou a defender que a imigração para os cafezais do oeste paulista só poderia ser vantajosa se o Estado - e não os fazendeiros - pagasse integralmente a passagem dos lavradores. ${ }^{64}$

Nem mesmo toda a produção das colônias de parceria dos Vergueiro conseguiu obstar a decadência de Ibicaba. Em 30 de maio de 1877, o governo de São Paulo enviou cinquenta soldados à fazenda para fazer cumprir uma ordem de penhora concedida ao London and Brazilian Bank. Desta feita, a chegada das tropas motivou diversos escravizados a fugirem inspirados pela animosidade dos fazendeiros locais contra os britânicos. ${ }^{65}$ Nos jornais, José Vergueiro publicou anúncios por vários meses em busca dos trabalhadores perdidos, recomendando especialmente a captura de Miguel, homem "crioulo letrado e cantador de modinhas,” além de José Antônio e Jesuíno, ambos escravizados que haviam escapado "com roupas de algodão de fábrica com o carimbo de Ibicaba". ${ }^{66} \mathrm{O}$ medo de uma rebelião negra levou Vergueiro a chamar a atenção do público leitor para a falsidade da filantropia britânica no Brasil, em tudo reminiscente da época da abolição do tráfico de escravizados. Escreveu ele no Correio Paulistano que "é certo que escravos, incitados por agentes que talvez não compreendam os perigos de perturbar a sociedade quando um elemento secular é ameaçado, podem em sua ignorância sustentar esperanças improvisadas baseadas em fantásticas promessas de nações poderosas”. Após contestar a penhora de Ibicaba por meios legais, José Vergueiro conseguiu manter o controle de sua plantação, mas não de seus trabalhadores. Mais do que perdas financeiras, ele protestou contra "a invasão de Ibicaba” pela força provincial armada que alimentou "o espírito de insubordinação e rebelião há muito latente no elemento escravo”. ${ }^{67}$

64 Correio Paulistano, 11 out. 1870 ש.

65 Correio Paulistano, 27 jun. 1877 ש.

66 Diário de São Paulo, 27 jun. 1877 ש.

67 Correio Paulistano, 14 jul. 1877 ש. 
Os escravizados de Limeira testemunharam a chegada das tropas a bordo de um trem especial supostamente solicitado pelos britânicos e falaram sobre a possibilidade de "nações poderosas imporem o decreto de sua vontade soberana sobre o governo imperial”. Vergueiro criticou duramente a conduta dos representantes britânicos como ilógica, dada a história da "violência [inglesa] exercida contra o Brasil por causa da escravidão", que incluía a ocupação brutal dos portos brasileiros, desrespeito às autoridades e uma marca de "filantropia sublime". ${ }^{68}$ Outros proprietários locais corroboraram os rumores de revolta escrava. Em carta publicada novamente no Correio Paulistano, um fazendeiro anônimo comentou que entre os escravizados "brotou o pensamento de que dos ingleses virá a emancipação. Dar 50 tropas aos ingleses que reclamam contra os donos de Ibicaba e permitir que fiquem soldados no município é o mesmo que acender uma chama em uma mina de pólvora”. Era como se as autoridades tivessem se esquecido da década de 1850, quando o fim do tráfico de africanos combinado às malogradas tentativas de colonização estrangeira desencadeara uma onda de conspirações por todo oeste paulista.

\section{Considerações finais}

Em 1859, o deputado paulista A. Cruz argumentou, em sessão na Assembleia de São Paulo, que a diversidade dos trabalhadores presentes nos cafezais da província justificava a presença fixa de um destacamento policial em lugares como Limeira. Referindo-se à história de rebeliões negras na região, disse ele:

Estas tentativas de tempos em tempos aparecem e com caráter bem aterrador; em 1848 descobriu-se em Campinas um plano horrível nesse

68 Correio Paulistano,13 jun. 1877 ש. 
sentido, depois outro abortou em S. Roque e Indaiatuba, em Taubaté creio que em 1852 ou 53, e o ano passado no Bananal como vistes no relatório de s. exc. Portanto é evidente que ao menos nos municípios que conta em seu seio grande número de escravos, como Bananal, Taubaté, Pindamonhangaba, Campinas, Constituição, Limeira, e Rio Claro, deve nele existir um destacamento suficiente [...].

E com especialidade chamo a atenção do governo para os últimos quatro municípios, de que acabo de falar, porque além dos braços escravos contêm neles grande número de alemães estabelecidos em várias colônias, que por sua raça, qualidades, usos e costumes formam um elemento heterogêneo, e outro de que se compõem a classe de nossos trabalhadores escravos, esta aglomeração de dois elementos heterogêneos naturalmente há de produzir algum desgosto, algum choque; do qual pode vir graves males a nossos lavradores; além disso a maior parte, desses colonos, por mais bem acolhidos e tratados que sejam por nossos patrícios, não se sujeitam com gosto e prazer a sua sorte e condição. ${ }^{69}$

Para o deputado, a presença de “elementos heterogêneos” no complexo cafeeiro era assunto de segurança pública e pesava sobre o Estado a tarefa de controlar o descontentamento geral que sempre beirava a revolta. Ao explicar a necessidade de vigiar colonos e escravizados, o deputado Cruz tocou em implicações importantes do projeto colonizador no Brasil. A convivência entre suíços, alemães, belgas, portugueses e africanos numa fronteira agrícola em expansão acentuou a circulação de ideias que desafiavam a ordem escravista. As trajetórias transnacionais de atores subalternos inseriam o país continuamente em embates políticos internacionais, comprometendo o avanço da disciplina senhorial. A crítica que imigrantes de língua alemã fizeram ao sistema de parceria escancarou a

69 Correio Paulistano, 28 fev. 1859. 
lógica escravista por trás do pioneirismo de Ibicaba, enriquecendo a alfabetização geopolítica dos trabalhadores escravizados pelo senador Vergueiro.

O colono que aceitava o contrato de parceria no Brasil esperava ser um imigrante autônomo que trabalhava para ganhar acesso à terra e desenvolver núcleos populacionais no futuro. Davatz e seus companheiros sonhavam em estabelecer uma colônia agrícola como as que então haviam no sul do país. Os cafeicultores, porém, jamais imaginaram uma sociedade composta de pequenas propriedades familiares durante o período imperial. Apostando na continuidade do sistema fundiário brasileiro baseado no latifúndio, homens como Vergueiro importavam imigrantes empobrecidos para empregá-los em posição de dependência em suas fazendas. Tal prática encontrava alento também na política agrária brasileira que, desde 1850, monetizara ainda mais a terra e regulamentara o uso de territórios devolutos.

Ao protagonizar conflitos trabalhistas no interior de regiões definidas pela numerosa presença africana, os colonos se tornaram parte do repertório variado de protesto acionado por comunidades negras na segunda metade do século XIX. A Revolta dos Parceiros de 1856 ganha assim, também, um lugar na história da emancipação no Brasil, dado que Ibicaba foi um macrocosmo da dinâmica que animava o abolicionismo negro ao redor do país. No rastro do contato com as correntes ideológicas de seu tempo, homens e mulheres escravizados continuaram a ler com cuidado o crescente questionamento da autoridade de seus senhores, imbuindo suas práticas de resistência com novos sentidos. Na década de 1850, muitos traduziram a pressão inglesa pela extinção do tráfico em aliança decisiva contra a escravidão no Brasil; nos anos 1860, outros fariam o mesmo ao saber da guerra seccional nos Estados Unidos. Tornado invisível por narrativas que privilegiaram o caráter inovador e nacionalista dos primeiros experimentos de colonização no oeste paulista, o pensamento geopolítico dos escravizados nos convida a repensar os mundos do trabalho rural em suas conexões com tradições rebeldes atlânticas. Enquanto existiu escravidão, a liberdade de todos 
foi sempre precária, abrindo espaço tanto para a reprodução de práticas coercitivas quanto para a interseção de lutas entre trabalhadores submetidos a diversos graus de servidão.

Recebido em 22 out. 2020

Aprovado em 1 dez. 2020

doi: 10.9771/aa.v0i63.42159 
Este artigo explora as relações entre escravizados e imigrantes europeus no oeste paulista tendo, como pano de fundo, a Revolta dos Parceiros, ocorrida em Limeira no ano de 1856. Considerado um marco na história da imigração no Brasil, o levante de colonos suíços contra o sistema de parceria na Fazenda Ibicaba contava também com o apoio dos cativos que trabalhavam nos cafezais adjacentes à Colônia Senador Vergueiro e demais fazendas vizinhas. Apagada pela historiografia, a conspiração negra de 1856 revela que a convivência entre colonos e escravizados no contexto do fim do tráfico acelerou a circulação de ideias sobre o fim da escravidão no Brasil. Ao retornar à Revolta em Limeira, este artigo aborda o encontro de perspetivas subalternas sobre o abolicionismo atlântico em Ibicaba para afirmar a geopolítica negra como elemento constituinte dos significados do mundo do trabalho na década de 1850.

Escravidão | Colonização | Revolta | Abolicionismo

\section{Crossing Paths at Ibicaba:}

SlaVes, SWiss ImMigrants, ANd ABolitionism during the Sharecroppers' Revolt (São Paulo, 1856-1857)

This article examines the relations between the enslaved and European immigrants in western São Paulo against the background of the 1856 Sharecroppers' Revolt that took place in Limeira. Considered a benchmark in the history of immigration in Brazil, the uprising of Swiss colonists against the "sistema de parceria" at the Ibicaba plantation also counted on support from enslaved populations in the vicinity of the Colônia Senador Vergueiro. Erased by the historiography, the 1856 black conspiracy shows that interactions between slaves and settlers in the context of the ban on the African slave trade sparked the circulation of abolitionist ideas in Brazil. By revisiting the revolt in Limeira, this paper explores how subaltern perspectives of the Atlantic world met in Ibicaba and claims a place for black geopolitics in defining Brazilian labor history in the 1850s.

Slavery | Colonization | Revolt | Abolitionism 